\title{
IL-1 $\beta$ induced protein changes in diabetes prone BB rat islets of Langerhans identified by proteome analysis
}

\author{
T. Sparre ${ }^{1}$, U. Bjerre Christensen ${ }^{1}$, P. Mose Larsen ${ }^{2}$, S. J. Fey ${ }^{2}$, K. Wrzesinski², P. Roepstorff ${ }^{3}$, \\ T. Mandrup-Poulsen ${ }^{1}$, F. Pociot ${ }^{1}$, A. E. Karlsen ${ }^{1}$, J. Nerup ${ }^{1}$ \\ ${ }^{1}$ Steno Diabetes Center, Gentofte, Denmark \\ ${ }^{2}$ Center for Proteome Analysis, Odense, Denmark \\ ${ }^{3}$ Institute for Biochemistry and Molecular Biology, University of Southern Denmark, Odense, Denmark
}

\section{Abstract}

Aims/hypothesis. Type I (insulin-dependent) diabetes mellitus is characterized by selective destruction of the insulin producing beta cells. Interleukin- $1 \beta$ (IL-1 $\beta$ ) modulates the beta-cell function, protein synthesis, energy production and causes apoptosis. We have previously shown changes in the expression of 82 out of 1815 protein spots detected by two dimensional gel electrophoresis in IL- $1 \beta$ exposed diabetes prone Bio Breeding (BB-DP) rat islets of Langerhans in vitro. The aim of this study was to identify the proteins in these 82 spots by mass spectrometry and compare these changes with those seen in IL-1 $\beta$ exposed Wistar Furth (WF) rat islets.

Methods. The 82 protein spots, that changed expression after IL-1 $\beta$ exposure, were all re-identified on preparative gels of 200000 neonatal WF rat islets, cut out and subjected to mass spectrometry for identification.
Results. Forty-five different proteins were identified from 51 spots and grouped according to function: (i) energy transduction and redox potentials; (ii) glycolytic and Krebs cycle enzymes; (iii) protein, DNA and RNA synthesis, chaperoning and protein folding; (iv) signal transduction, regulation, differentiation and apoptosis; (v) cellular defence; and (vi) other functions. Comparison of IL-1 $\beta$ exposed BB-DP and WF islets showed common changes in 14 proteins and several proteins influencing similar pathways, suggesting that similar routes in the two strains lead to beta-cell destruction.

Conclusion/interpretation. We demonstrate that proteome analysis is a powerful tool to identify proteins and pathways in BB-DP rat islets exposed to IL-1 $\beta$. [Diabetologia (2002) 45:1550-1561]

Keywords Proteome analysis, two dimensional gel electrophoresis, mass spectrometry, cytokines, IL-1 $\beta$, $\mathrm{BB}$ rat, diabetes, pathogenesis.
Received: 17 June 2002 / Revised: 18 July 2002

Published online: 18 September 2002

(C) Springer-Verlag 2002

Corresponding author: J. Nerup, MD, DMSc, Steno Diabetes Center, Niels Steensensvej 2, DK-2820 Gentofte, Denmark. E-mail: nerup@pres.dk

Abbreviations: 2-DGE, Two dimensional gel electrophoresis; BB-DP, diabetes prone Bio Breeding; WF, Wistar Furth; NO, nitric oxide; iNOS, inducible NO syntase; BN, Brown Norway; LS, Lewis-Scripps; HSP, heat shock protein; HBSS, Hanks' balanced salt solution; pI, isoelectric point; TCA, tricholroacetic acid; IEF, isoelectric focusing; NEPHGE, non-equilibrium $\mathrm{pH}$-gradient electrophoresis; MALDI, matrix-assisted laser desorption/ionisation; GRP, glucose regulated protein; GABA, gamma-aminobutyric acid; GAD, glutamic acid decarboxylase; NOD, non obese diabetic; PIPP, pertubation in protein patterns.
Type I (insulin-dependent) diabetes mellitus is a multifactorial polygenic autoimmune disease characterized by mononuclear cell infiltration in the islets of Langerhans (insulitis) and selective destruction of the insulin producing beta cells $[1,2,3]$. It is generally accepted that the destruction of the beta cells results from interactions between various environmental factors and immune mechanisms in genetically susceptible people [3]. The very first events initiating the destructive process have not yet been described in detail. Cytokines, in particular interleukin-1 $\beta$ (IL-1 $\beta$ ), are known to be released within the islets in sufficient quantities to modulate and inhibit beta-cell function in vitro [4]. Furthermore, IL-1 $\beta$ influences many important cellular functions such as reducing DNA content, decreasing protein synthesis and intracellular energy 
production and inducing beta-cell apoptosis. During the destructive process IL-1 $1 \beta$, TNF- $\alpha$ and IFN- $\gamma$ are released in the islets resulting in the production of free radicals [e.g. nitric oxide $\left(\mathrm{NO}^{-}\right)$, super oxide $\left(\mathrm{O}_{2}^{-}\right)$and hydroxyl $\left.\left(\mathrm{OH}^{-}\right)\right]$in the beta cells [3]. Free radicals are normally scavenged by protective proteins [e.g. haeme oxygenases and manganese superoxide dismutase $(\mathrm{MnSOD})][5,6]$. Many IL-1 $\beta$ effects are mediated by inducing the inducible nitric oxide syntase (iNOS) and its product, nitric oxide [7]; however, NO-independent mechanisms also occur $[8,9,10]$. We hypothesize that the beta cell, when exposed to IL- $1 \beta$ initiates a protective response in competition with a series of deleterious events, and that in beta cells the deleterious events prevail [3]. In support of this, over-expression in islet cells of scavengers of free radicals, such as catalase and glutathione peroxidase, reduces the deleterious effects of cytokines on beta cells [11].

Our laboratories recently described in Wistar Furth (WF) rat islets exposed to IL- $1 \beta$ in vitro, changes in the expression of 105 out of approximately 1400 proteins identified by high resolution two dimensional gel electrophoresis (2-DGE) [8]. The majority of these proteins have been identified by mass spectrometry $[8,10]$ and identified proteins were classified into the following groups on the basis of their known and perceived function: (i) energy transduction and redox potential; (ii) glycolytic enzymes; (iii) protein synthesis chaperones and protein folding; (iv) signal tranduction, regulation, differentiation and apoptosis suggesting a broad variety of pathways involved in IL-1 $\beta$ mediated islet toxicity [10].

The diabetes prone BioBreeding (BB-DP) rat spontaneously develops a diabetic syndrome with characteristics in common with human Type I diabetes [12]. Originally the BB-DP rat strain was bred from a WF rat colony [13]. Strain-dependent variations in betacell sensitivity to IL-1 $\beta$ effects have been observed in vitro and in vivo $[14,15]$ with islets from Brown Norway (BN) rats being less sensitive to IL-1 $\beta$ compared to WF, Lewis-Scripps (LS) and BB-DP as well as diabetes resistant $\mathrm{BB}$ (BB-DR) rats. BB-DP rat islets produce lower protective stress responses [heat shock protein 70 (HSP70)] than BB-DR rat islets which can prime beta cells for destruction [16]. We have previously shown that there is no difference in nitric oxide (NO) production and 24-h accumulated insulin release in BB-DP and WF islets in response to exposure to $150 \mathrm{pg} / \mathrm{ml} \mathrm{IL-1 \beta}$ for $24 \mathrm{~h}$ [17]. The relative resistance to IL-1 $\beta$ induced inhibition of beta-cell function in vitro and in vivo in $\mathrm{BN}$ rat islets was associated with lower expression of inducible nitric oxide synthase (iNOS) compared to Wistar Kyoto and LS rat islets [15].

Proteome analysis applied to WF rat islets exposed to IL-1 $\beta$ has provided a detailed picture of beta-cell destruction at the protein level $[9,10]$. Comparison of IL- $1 \beta$ induced pertubation of protein patterns (PIPP), i.e. expression changes and or posttranslatory modifications, identified by proteome analysis in WF and BB-DP rat islets could identify proteins or pathways generally involved in beta-cell destruction as well as some specific for beta-cell destruction in the BB-DP rat. We previously showed by 2 -DGE that IL-1 $\beta$ induce reproducible and statistically significant changes in the expression of 82 protein spots in $\mathrm{BB}-\mathrm{DP}$ rat islets in vitro out of a total of 1815 protein spots [17].

The aim of this study was to identify the proteins in these 82 spots by mass spectrometry and to compare the findings with protein identifications from IL-1 $\beta$ exposed WF islets [10] and to describe briefly their known functions with respect to the pathogenesis of Type I diabetes for some of the proteins.

\section{Materials and methods}

Study design. Preparative gels of $200000 \mathrm{WF}$ islets were made to describe PIPP, which were originaly identified in BB-DP rat islets (analytical gels). For these analytical gels 150 neonatal BB-DP rat islets were incubated with $150 \mathrm{pg} / \mathrm{ml}$ recombinant human IL-1 $\beta$ for $24 \mathrm{~h}$ and labelled for 2 -DGE. In the analytical gels each protein spot was assigned a percentage of the total integrated optic density (\%IOD) on the gel by the BioImage computer programme. Expression changes were evaluated by a Student's $t$ test and considered significant at $p$ values below 0.01 [17]. For most proteins this reflects a twofold or higher change in expression. Protein spots that changed expression in BB-DP rat islets after exposure to IL- $1 \beta$ were all identified on preparative 2-D gels of WF rat islets (200 000 islets in total) and cut out of the preparative gels and subjected to mass spectrometry.

Reagents. RPMI 1640, Hanks' balanced salt solution (HBSS) and DMEM were purchased from Gibco, Paisley, Scotland. RPMI 1640 contained $11 \mathrm{mmol}$ of D-glucose and was supplemented with $20 \mathrm{mmol} / \mathrm{l}$ HEPES buffer, $100000 \mathrm{IU} / \mathrm{l}$ penicillin and $100 \mathrm{mg} / \mathrm{l}$ streptomycin. Recombinant human IL-1 $\beta$ (specific activity was $400 \mathrm{U} / \mathrm{ng}$ ) was from Novo Nordisk, Bagsvaerd, Denmark. Other reagents used in the study were: 2-mercaptoethanol, foetal calf serum (BSA), normal human serum (NHS), Tris $\mathrm{HCl}$, Tris base, glycine, (Sigma, St. Louis, Mo., USA); trichloracetic acid (TCA), phosphoric acid, $\mathrm{NaOH}$, glycerol, n-butanol, bromophenol blue, $\mathrm{H}_{3} \mathrm{PO}_{4}$ and $\mathrm{NaNO}_{2}$ (Merck, Darmstadt, Germany); filters (HAWP $0.25 \mathrm{~mm}$ pore size) (Millipore, Boston, Mass., USA); RNA'se A, DNA'se I (Worthington, Freehold, N.J., USA); [ ${ }^{35}$ S]-methionine (SJ 204, specific activity: $>1000 \mathrm{Ci} / \mathrm{mmol}$, containing $0.1 \%$ 2-mercaptoethanol), Amplify (Amersham International, Amersham, UK); urea (ultra pure) (Schwarz/Mann, Cambridge, Mass., USA); acrylamide, bisacrylamide, 4N-tetra-methyl-ethylenediamine (TEMED), ammonium persulphate (BioRad, Richmond, Calif., USA); ampholytes: pH 5-7, pH 3.5-10, pH 7-9, pH 8-9.5 (Amasham Biotech, Sweden); Nonidet P-40 (BDH, Poole, UK); ampholytes: $\mathrm{pH}$ 5-7 and sodium dodecyl sulphate (Serva, Heidelberg, Germany); agarose (Litex, Copenhagen, Denmark); ethanol (absolute 96\%) (Danish Distillers, Aalborg, Denmark); methanol (Prolabo, Brione Le Blanc, France); acetic acid (technical quality, 99\% glacial) (Bie and Berntsen, Århus, Denmark) and X-ray film (Curix RP-2) (AGFA). 
Animals. BB-DP (BB/Wor/Mol-BB2) rats and pregnant inbred WF rats were purchased from M \& B, Ll. Skensved, Denmark. All animal experiments were carried out according to national and international law and ethical standards. The experiments were approved by the Danish Council for Animal Welfare under the Ministry of Justice.

Isolation, culture and labelling of islets for preparative gels. Islets were isolated by collagenase digestion of the pancreata from 4 to 5 day old WF rats [18]. After 4 days of preculture in RPMI $1640+10 \%$ FCS, islets were incubated for $24 \mathrm{~h}$ in $37^{\circ} \mathrm{C}$ humidified atmospheric air in $300 \mu \mathrm{l}\left(150\right.$ islets for $\left[{ }^{35} \mathrm{~S}\right]$ methionine labelling as tracer islets) or $3000 \mu \mathrm{l}$ (40 000 non-labelled islets for preparative gels each) RPMI $1640+0.5 \%$ normal human serum. Next islets were washed twice in HBSS. Tracer islets were labelled for $4 \mathrm{~h}$ at $37^{\circ} \mathrm{C}$ in $200 \mu \mathrm{l}$ homemade methionine-free DMEM with $10 \%$ dialysed NHS, and $200 \mu \mathrm{Ci}$ $\left.{ }^{35} \mathrm{~S}\right]$-methionine and the islets for the preparative gels were incubated in the same way in $3000 \mu$ methionine containing DMEM without adding $\left[{ }^{35} \mathrm{~s}\right]$-methionine. To eliminate 2 -mercaptoethanol, $\left.{ }^{35} \mathrm{~S}\right]$-methionine was freeze-dried for at least $4 \mathrm{~h}$ before labelling. After labelling and incubation, the islets were washed thrice in HBSS, the supernatant was removed and islets were immediately frozen at $-80^{\circ} \mathrm{C}$. Unlabelled islets for preparative gels were washed twice in HBSS and snapfrozen. For localization of the spots, radioactively labelled tracer islets were mixed with the non-labelled islets.

The BB-DP islets used for the analytical 2-D gels were isolated and treated as described above. During incubation period islets were exposed either to $150 \mathrm{pg} / \mathrm{ml}$ recombinant human IL-1 $\beta$ or served as control islets in three independent experiments [17].

Sample preparation. The frozen islets were re-suspended in $100 \mu \mathrm{LNAseI/RNAse} \mathrm{A} \mathrm{solution} \mathrm{and} \mathrm{lysed} \mathrm{by} \mathrm{freeze-thawing}$ twice. After the second thawing, the samples were left on ice for $30 \mathrm{~min}$ to digest the nucleic acids and then freeze dried overnight. The samples were dissolved by shaking in $120 \mu \mathrm{l}$ lysis buffer ( $8.5 \mathrm{~mol} / 1$ urea, 2\% Nonidet P-40, 5\% 2-mercaptoethanol and $2 \%$ ampholytes, $\mathrm{pH}$ range $7-9$ ) for a minimum of $4 \mathrm{~h}$.

Measurement of $\left[{ }^{35} S\right]$-methionine incorporation. The amount of $\left[{ }^{35} \mathrm{~s}\right]$-methionine incorporation was quantified by adding $10 \mu \mathrm{FCS}\left(0.2 \mu \mathrm{g} / \mathrm{ml} \mathrm{H}_{2} \mathrm{O}\right)$ as a protein-carrier to $5 \mu \mathrm{l}$ of a $1: 10$ dilution of each sample in duplicate, followed by $0.5 \mathrm{ml}$ of $10 \%$ TCA. This was left to precipitate for $30 \mathrm{~min}$ at $4^{\circ} \mathrm{C}$ before being filtered through $0.25 \mu \mathrm{m}$ hydroxy appatit-WP (HAWP) filters. The filters were dried and placed into scintillation liquid for counting.

2-DGE and preparative gels. The labelled gels of WF islets were produced in the same way as the analytical gels of IL-1 $\beta$ exposed and control BB-DP islets, each in batches of 150 islets [17]. Preparative two dimensional gels (2-DG) were produced from a pool of approximately 200000 neonatal WF rat islets isolated, cultured, labelled and separated on gels as described above. For localization of the spots, radioactively labelled tracer islets were mixed with the non-labelled islets.

The procedure has been described previously [19, 20, 21]. Briefly, first dimension gels contained $4 \%$ acrylamide, $0.25 \%$ bisacrylamide, ampholytes and nonidet P-40. Equal amount of protein (175-200 $\mu \mathrm{g}$ for preparative gels) and counts per min $\left(10^{6} \mathrm{cpm}\right)$ of each sample were applied to the gels. Both isoelectric focusing (IEF; $\mathrm{pH} 3.5-7$ ) and non-equilibrium $\mathrm{pH}$-gradient electrophoresis (NEPHGE; pH 6.5-10.5) gels were made. Second dimension gels contained $12.5 \%$ acrylamide and $0.063 \%$ bisacrylamide and were run overnight. After electrophoresis, the gels were fixed and treated for fluorography with Amplify before being dried. The gels were placed in contact with X-ray films and exposed at $-70^{\circ} \mathrm{C}$ for 3 to 40 days. Each gel was exposed for at least three time periods to compensate for the lack of dynamic range of X-ray films.

Neonatal WF rat islets were used for preparative gels because of the price and higher number of islets isolated per animal. The cost of one WF rat is approximately one tenth of the price of a BB-DP rat (approximately 100 US\$ each). From each rat it was possible to isolate 150 to 200 islets. All protein spots changing expression after IL-1 $\beta$ exposure of BB-DP rat islets were also identified in the WF islet preparative 2-D gels. Notably, no protein spots were expressed de novo after IL-1 $\beta$ exposure of BB-DP islets. Hence, preparative gels from WF rat islets were suitable for mass spectrometry identification of proteins in the spots that changed expression in IL-1 $\beta$ exposed BB-DP islets.

Determination of $M_{r}$ and $\mathrm{pI}$. Molecular weight and $\mathrm{pI}$ for individual proteins on the gels were interpolated from landmark proteins. Landmark proteins were determined using internal standards and pI calibration kits [20]. Theoretical $\mathrm{M}_{\mathrm{r}}$ and $\mathrm{pI}$ were calculated using the Compute $\mathrm{pI}$ and $\mathrm{Mw}$ tool at the ExPASy Molecular Biology Server [22].

Computer analysis of fluorographs. Computer analysis was carried out using the BioImage program 2D-Analyzer (version 6.1) [17].

Protein identification by matrix-assisted laser desorption/ ionization (MALDI) mass spectrometry. Briefly, the 82 protein spots of interest were obtained by cutting them out of the dried gel using a scalpel. The proteins were enzymatically digested in the gel piece as described $[23,24]$ with minor modifications [25]. The excised gel pieces were washed in $50 \mathrm{mmol} / \mathrm{l}$ $\mathrm{NH}_{4} \mathrm{HCO}_{3}$ and acetonitrile (60/40) and dried by vacuum centrifugation. Modified porcine trypsin (12 ng/ $\mu$ l, Promega, sequencing grade) in digestion buffer $\left(50 \mathrm{mmol} / \mathrm{NH}_{4} \mathrm{HCO}_{3}\right)$ was added to the dry gel pieces and incubated on ice for $1 \mathrm{~h}$ for reswelling. After removing the supernatant, 20 to $40 \mu \mathrm{l}$ digestion buffer was added and the digestion was continued at $37^{\circ} \mathrm{C}$ for 4 to $18 \mathrm{~h}$. The peptides were extracted as described [24] and dried in a vacuum centrifuge. The residue was dissolved in $5 \%$ formic acid and analysed by MALDI mass spectrometry. Delayed extraction MALDI mass spectra of the peptide mixtures were acquired using a Bruker Reflex time-of-flight mass spectrometer (Bruker AG, Germany). Samples were prepared using $\alpha$-cyano-4-hydroxy cinnamic acid as matrix [26]. Proteins were identified by in silico comparison of the theoretical peptide-mass maps in the comprehensive, non-redundant protein sequence database (NRDB, European Bioinformatics Institute, Hinxton, UK [27]) using the PeptideSearch software ([28] further developed at EMBL; Heidelberg, Germany), SWISS-PROT [29], PIR [30], NIH and GENEBANK [31]. The protein identifications were examined using the "second pass search" feature of the software and critical evaluation of the peptide mass map as described [32].

Protein information. Information about the known proteins identified and putative biological functions were found at the ExPASy Molecular Biology Server at SWISS-PROT [29] and at The National Centre for Biotechnology Information (NCBI) [31]. 


\section{NEONATAL BB-DP rat islets}

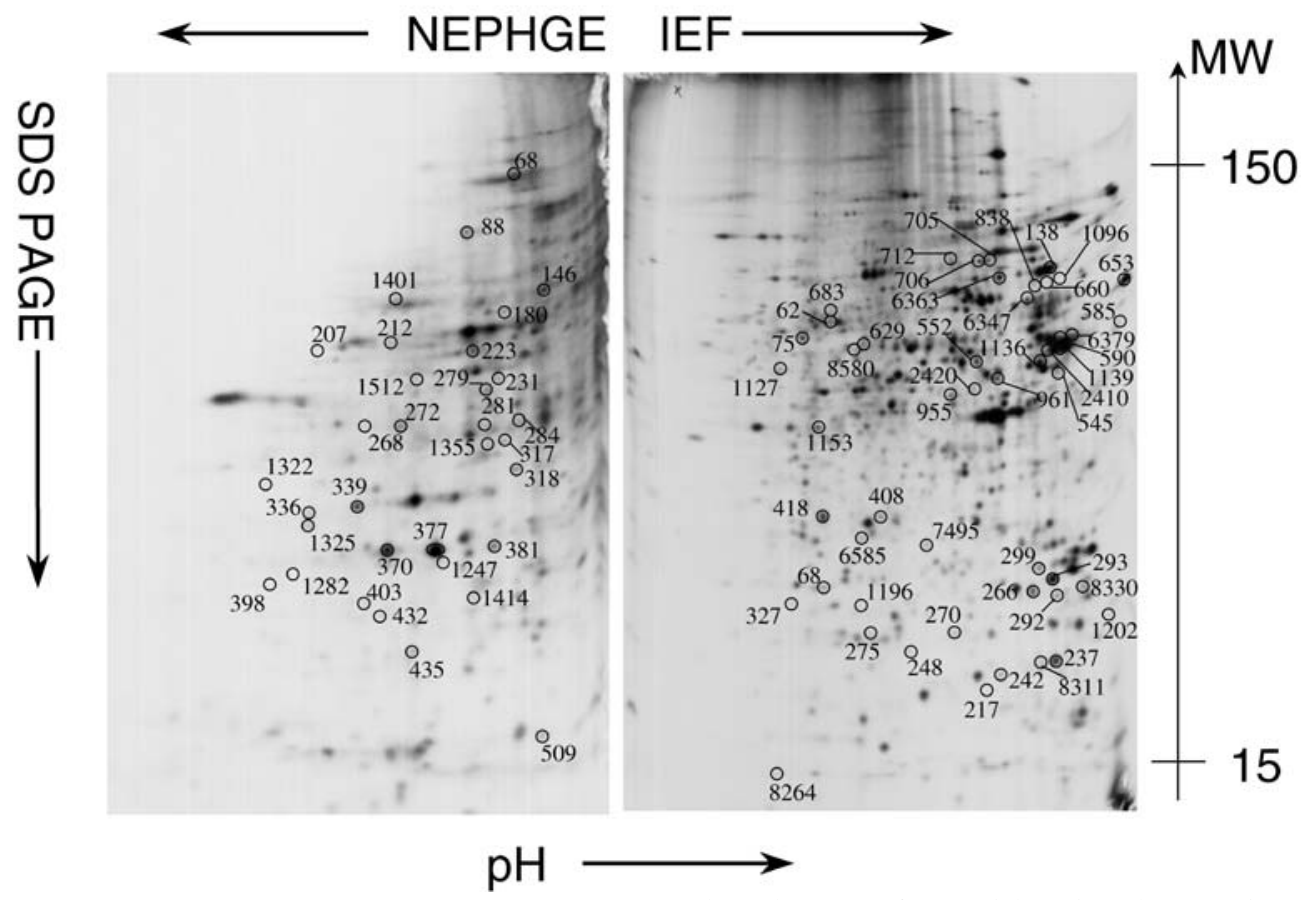

Fig. 1. Two-dimensional gel of neonatal BB-DP rat islets of Langerhans incubated for $24 \mathrm{~h}$ in RPMI 1640 supplemented with $0.5 \%$ NHS followed by $4 \mathrm{~h}$ of labelling with $\left[{ }^{35} \mathrm{~s}\right]-$ methionine. The gel shown is representative of three independent experiments and the marked proteins represent proteins changing expression after $24 \mathrm{~h}$ of exposure to IL-1 $\beta$. IEF gel ( $\mathrm{pH} 3.5-7$ ) on the right side and NEPHGE gel $(\mathrm{pH} 6.5-10.5)$ on the left side. The numbers correspond to the proteins in Tables 1 and 2. For technical reasons a representative gel of control islets is presented, since most proteins are down-regulated after IL-1 $\beta$ exposure (Table 1,2).

\section{Results}

All 82 significantly changed protein spots were reidentified in preparative gels of neonatal WF islets and could be excised from the gels for mass spectrometry identification (Fig. 1). Positive identification was obtained for a total of 45 different proteins from 51 of the 82 spots (Table 1). Six spots contained two identifiable proteins (NEPHGE match no. 339, 370 and IEF $955,248,1136,660)$. Some proteins were present in more than one spot: three proteins were present in two spots (Heterogeneous nuclear ribonucleoproteins A2/B1, calreticulin and NADH dehydrogenase), three proteins were present in three spots [malate dehydrogenase precursor (mitochondrial), IgE binding protein and glucose-regulated protein 78 (GRP 78)] and one protein, tubulin beta- 5 chain was present in four spots. The presence of the same protein in more than one spot suggests that the protein exists in different posttranslatory modified or degraded forms. Positive identification was not obtained for 31 protein spots either due to spectra with no data base match $(n=16)$ or low abundance of peptides in the excised and digested spots $(n=15)$ (Table 2$)$. Thus, the success rate of positively identified protein spots was $62 \%$ (51 spots out 82). A similar result, 60 spots identified out of 105 (58\%) were obtained from WF rat islets exposed to IL-1 $\beta$, corresponding to 57 different proteins [10]. Out of 14 proteins 12 were identified both in BB-DP and WF rat islets as identical [NEPHGE match no. 223, 231, 370, 146, 381, 377, $398(381,377$ and 398 are all galectin-3), IEF match no. 552, 138, 660, 6347 (138, 660 and 6347 are all GRP 78), 1136, 8580, 68, 62, 6363], one was an iso-form (IEF match no. 955) and one a post translatory modified form (IEF match no. 1127) (Table 1).

Minor differences in $\mathrm{M}_{\mathrm{r}}$ and $\mathrm{pI}$ values observed between proteins identified both in BB-DP and WF islets can be explained in that the gel concentrations in the two studies were different. First dimension gels were run identically for BB-DP and WF islets. However, second dimension analytical and preparative WF islet gels were run on $10 \%$ and $15 \%$ acrylamide gels in the WF islet study [10] whereas the analytical BB-DP gels were run on $12.5 \%$ acrylamide gels as were the preparative WF gels for this study. Furthermore, using the latest updated version of the protein databases and depending on the actual peptides used from the mass spectrometry spectra to identify the protein, different species can give the highest score, although it is the same protein.

In Table 1 , the protein $\mathrm{M}_{\mathrm{r}}$ 's and $\mathrm{pI}$ 's observed on the gels are presented together with the computed theoretical $\mathrm{M}_{\mathrm{r}}$ and $\mathrm{pI}$ values. Differences in observed and computed values of $\mathrm{M}_{\mathrm{r}}$ and $\mathrm{pI}$ could be due to posttranslatory modifications, degradation or pro- or 
Table 1. Identification of proteins induced by IL-1 $\beta$ in BB-DP rat islets

\begin{tabular}{|c|c|c|c|c|c|c|c|c|c|}
\hline $\begin{array}{l}\text { Gel } \\
\text { match } \\
\text { No. }\end{array}$ & $\begin{array}{l}\% \\
\text { IOD }\end{array}$ & $\begin{array}{l}\% \\
\text { IOD } \\
\text { ratio }\end{array}$ & Protein name & Function & $\begin{array}{l}\text { Database } \\
\text { acc. no. }\end{array}$ & $\mathrm{M}_{\mathrm{r}}$ & $\begin{array}{l}\text { Theo- } \\
\text { retical } \\
M_{r}\end{array}$ & $\mathrm{pI}$ & $\begin{array}{l}\text { Theo- } \\
\text { retical } \\
\text { pI }\end{array}$ \\
\hline
\end{tabular}

\section{Energy transduction and redox potentials}

\begin{tabular}{|c|c|c|c|}
\hline N 318 & 0.165 & 0.56 & Alcohol dehydrogenase \\
\hline $\mathrm{N} 231^{\mathrm{b}}$ & 0.041 & 0.51 & $\begin{array}{l}\text { ATP synthase alpha chain, } \\
\text { mitochondrial precursor }\end{array}$ \\
\hline $\mathrm{N} \mathrm{370}$, b & 2.055 & 0.24 & $\begin{array}{l}\text { L-3-hydroxyacyl-CoA } \\
\text { dehydrogenase precursor }\end{array}$ \\
\hline N 1247 & 0.084 & 0.20 & Carbonyl reductase \\
\hline I $955^{\mathrm{a}} \mathrm{b}$ & 0.104 & 2.41 & Creatine kinase-B \\
\hline I $1136^{a}$ & 0.405 & 0.45 & $\begin{array}{l}\mathrm{H}+\text { transporting ATP } \\
\text { synthase }\end{array}$ \\
\hline I 706 & 0.086 & 0.43 & NADH dehydrogenase \\
\hline I 705 & 0.084 & 0.35 & NADH dehydrogenase \\
\hline $\mathrm{I} 552^{\mathrm{b}}$ & 0.132 & 0.07 & $\begin{array}{l}\text { ATPase, } \mathrm{H}+\text { transporting, } \\
\text { lysosomal (vacuolar proton } \\
\text { pump), beta polypeptide, } \\
56 / 58 \mathrm{kD} \text {, isoform } 1\end{array}$ \\
\hline
\end{tabular}

\begin{tabular}{|c|c|c|c|c|c|}
\hline Redox potential & gi 1703237 & 42.4 & 36.4 & 7.8 & 6.8 \\
\hline Energy transduction & gi 114523 & 51.1 & 58.8 & 7.9 & 9.2 \\
\hline $\begin{array}{l}\text { Energy transduction, } \\
\text { redox potential }\end{array}$ & gi 5353512 & 36.5 & 34.3 & 8.4 & 89 \\
\hline Redox potential & gi 1352258 & 37.7 & 30.4 & 8.2 & 2 \\
\hline Energy transduction & gi 203476 & 49.3 & 42.7 & 5.4 & .3 \\
\hline Energy transduction & gi 92350 & 52.9 & 56.4 & 4.8 & \\
\hline Energy transduction & gi 4826856 & 86.7 & 79.6 & 5.3 & \\
\hline Energy transduction & gi 4826856 & 87.3 & 79.6 & 5.2 & \\
\hline Energy transduction, & gi 4502309 & 57.6 & 57.0 & 5.3 & \\
\hline
\end{tabular}

\section{Glycolytic and Krebs cycle enzymes}

\begin{tabular}{|c|c|c|c|c|c|c|c|c|c|}
\hline I 629 & 0.065 & 2.15 & $\begin{array}{l}\text { Glucose-6-phosphate } \\
\text { dehydrogenase }\end{array}$ & Energy generation & gi 204197 & 61.8 & 59.2 & 6.0 & 6.0 \\
\hline I $1127^{b}$ & 0.067 & 0.29 & $\begin{array}{l}\text { Glyceraldehyde-3-phosphate } \\
\text { dehydrogenase }\end{array}$ & Energy generation & gi 203142 & 54.4 & 35.7 & 6.7 & 8.4 \\
\hline $\mathrm{N} 223^{\mathrm{b}}$ & 0.379 & 0.52 & Pyruvate kinase M2 isozyme & Energy generation & gi 1346398 & 55.6 & 57.6 & 8.0 & 7.4 \\
\hline N 88 & 0.288 & 0.41 & $\begin{array}{l}\text { Aconitate hydratase, } \\
\text { mitochondrial precursor }\end{array}$ & Energy generation & gi 1351857 & 77.8 & 85.4 & 7.3 & 8.1 \\
\hline N 272 & 0.433 & 0.48 & $\begin{array}{l}\text { Isocitrate dehydrogenase } 2 \text {, } \\
\text { mitochondrial }\end{array}$ & Energy generation & gi 6680343 & 45.9 & 58.7 & 8.4 & 8.9 \\
\hline N 1325 & 0.137 & 0.38 & $\begin{array}{l}\text { Malate dehydrogenase } \\
\text { precursor, mitochondrial }\end{array}$ & Energy generation & gi 319830 & 41.9 & 35.5 & 9.0 & 8.9 \\
\hline N 336 & 0.118 & 0.36 & $\begin{array}{l}\text { Malate dehydrogenase } \\
\text { precursor, mitochondrial }\end{array}$ & Energy generation & gi 319830 & 42.7 & 35.5 & 9.0 & 8.9 \\
\hline N 339a & 0.830 & 0.28 & $\begin{array}{l}\text { Malate dehydrogenase } \\
\text { precursor, mitochondrial }\end{array}$ & Energy generation & gi 319830 & 40.4 & 35.5 & 8.7 & 8.9 \\
\hline
\end{tabular}

Protein synthesis (incl. DNA/RNA processing and synthesis, purin/pyrimidine synthesis, amino acid metabolism) chaperones and protein folding

\begin{tabular}{|c|c|c|c|c|c|c|c|c|c|}
\hline N $146^{b}$ & 0.590 & 0.44 & $\begin{array}{l}\text { 5-aminoimidazole- } \\
\text { 4-carboxamide ribonucleotide } \\
\text { formyltransferase }\end{array}$ & $\begin{array}{l}\text { Purine/pyrimidine } \\
\text { synthesis, DNA/RNA } \\
\text { synthesis }\end{array}$ & gi 2541906 & 64.8 & 64.2 & 6.9 & 6.7 \\
\hline I $248^{a}$ & 0.030 & 0.48 & $\begin{array}{l}\text { Adenosine } \\
\text { phosphoribosyltransferase }\end{array}$ & $\begin{array}{l}\text { Purine/pyrimidine } \\
\text { synthesis, DNA/RNA } \\
\text { synthesis }\end{array}$ & gi 543829 & 21.5 & 19.5 & 5.7 & 6.2 \\
\hline I $248^{\mathrm{a}}$ & 0.030 & 0.48 & UMP-CMP kinase & $\begin{array}{l}\text { Purine/pyrimidine } \\
\text { synthesis, DNA/RNA } \\
\text { synthesis }\end{array}$ & gi 5730476 & 21.5 & 22.2 & 5.7 & 5.4 \\
\hline N 1414 & 0.070 & 0.41 & $\begin{array}{l}\text { Heterogeneous nuclear } \\
\text { ribonucleoprotein A2/B1 }\end{array}$ & RNA-processing & gi 6647752 & 42.1 & 36.0 & 8.0 & 8.7 \\
\hline N 339a & 0.830 & 0.28 & $\begin{array}{l}\text { Heterogeneous nuclear } \\
\text { ribonucleoprotein A2/B1 }\end{array}$ & RNA-processing & gi 6647752 & 40.4 & 36.0 & 8.7 & 8.7 \\
\hline N 1401 & 0.482 & 0.17 & M4 protein deletion mutant & RNA-processing & gi 3126878 & 64.4 & 77.5 & 8.5 & 8.9 \\
\hline N 317 & 0.071 & 0.35 & $\begin{array}{l}\text { Aspartate transaminase, } \\
\text { cytosolic }\end{array}$ & $\begin{array}{l}\text { Amino acid } \\
\text { metabolism }\end{array}$ & gi 91997 & 44.9 & 46.2 & 7.9 & 6.3 \\
\hline N 1322 & 0.054 & 0.15 & $\begin{array}{l}\text { Aspartate aminotransferase, } \\
\text { mitochondrial precursor }\end{array}$ & $\begin{array}{l}\text { Amino acid } \\
\text { metabolism }\end{array}$ & gi 112987 & 47.6 & 47.3 & 9.1 & 9.1 \\
\hline I 237 & 0.534 & 0.12 & 60 ribosomal protein L11 & Ribosome protein & gi 971761 & 20.9 & 18.8 & 4.4 & 9.9 \\
\hline I 653 & 0.722 & 1.52 & Calreticulin & $\begin{array}{l}\text { Chaperone, } \\
\text { transcription factor }\end{array}$ & gi 6680836 & 120.7 & 48.0 & 3.7 & 4.3 \\
\hline
\end{tabular}


Table 1 (continued)

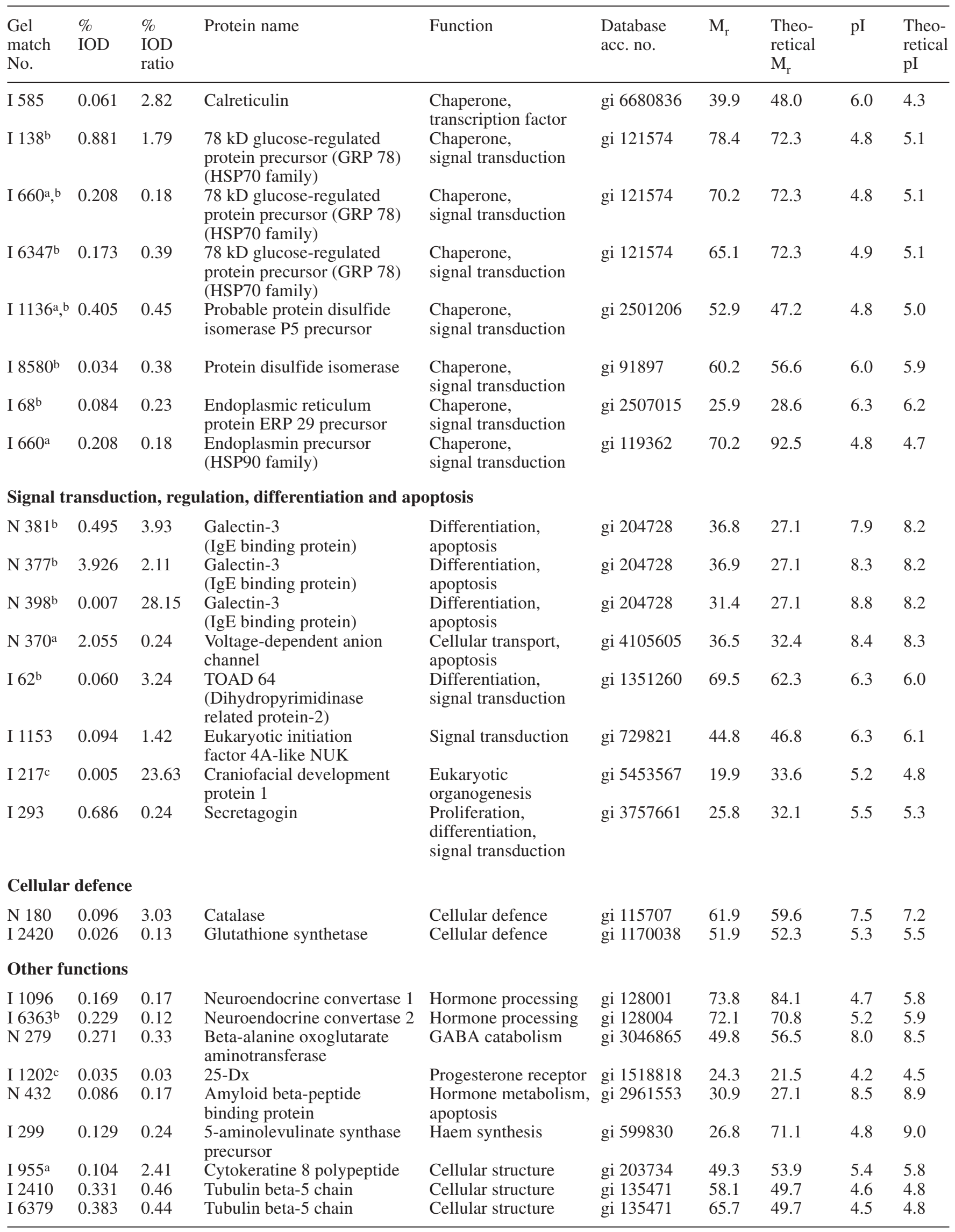


Table 1 (continued)

\begin{tabular}{|c|c|c|c|c|c|c|c|c|c|}
\hline $\begin{array}{l}\text { Gel } \\
\text { match } \\
\text { No. }\end{array}$ & $\begin{array}{l}\% \\
\text { IOD }\end{array}$ & $\begin{array}{l}\% \\
\text { IOD } \\
\text { ratio }\end{array}$ & Protein name & Function & $\begin{array}{l}\text { Database } \\
\text { acc. no. }\end{array}$ & $\mathrm{M}_{\mathrm{r}}$ & $\begin{array}{l}\text { Theo- } \\
\text { retical } \\
\mathrm{M}_{\mathrm{r}}\end{array}$ & $\mathrm{pI}$ & $\begin{array}{l}\text { Theo- } \\
\text { retical } \\
\text { pI }\end{array}$ \\
\hline I 590 & 0.485 & 0.41 & Tubulin beta- 5 chain & Cellular structure & gi 135471 & 64.9 & 49.7 & 4.5 & 4.8 \\
\hline I 1139 & 0.561 & 0.37 & Tubulin beta- 5 chain & Cellular structure & gi 135471 & 59.5 & 49.7 & 4.6 & 4.8 \\
\hline $\mathrm{N} 1512^{\mathrm{c}}$ & 0.038 & 0.14 & $\begin{array}{l}\text { Immediate-early protein } \\
1 \text { rat cytomegalovirus }\end{array}$ & $\begin{array}{l}\text { Virus protein, } \\
\text { transcription factor }\end{array}$ & gi 543613 & 51.6 & 66.7 & 8.4 & 4.7 \\
\hline
\end{tabular}

Match numbers are arbitrary numbers given by the computer and correspond to the number of the spot in the gel. \% IOD refers to the integrated optic density on the control gels. \% IOD ratio refers to the ratio of integrated optical density between gels compared. Numbers below 1 indicate proteins down-regulated and numbers above 1 are up-regulated in islets exposed to IL-1 $\beta$. Spots on the NEPHGE side have prefix $\mathrm{N}$ and prefix I on the IEF side. Protein name refers to the name found in the NCBI database (http://www.ncbi.nlm.nih.gov) through the database accession number a Indicates spots whereby more than one protein was identified. Proteins mentioned more than once are found in more than one spot

b Proteins previously identified as changed in expression in WF rat islets exposed to IL-1 $\beta[10]$

c Proteins that have not been described previously or supposed to be present in islets
Table 2. Unidentified proteins

\begin{tabular}{|c|c|c|c|c|}
\hline $\begin{array}{l}\text { Match } \\
\text { No. }\end{array}$ & $\begin{array}{l}\% \\
\text { IOD } \\
\text { ratio }\end{array}$ & $\begin{array}{l}\text { Mass spectrometry } \\
\text { results }\end{array}$ & $\mathrm{M}_{\mathrm{r}}$ & $\mathrm{pI}$ \\
\hline N 1282 & 28.67 & No spectrum & 31.8 & 8.8 \\
\hline N 281 & 9.29 & No spectrum & 46.1 & 8.0 \\
\hline N 435 & 6.03 & Weak spectrum no id & 29.0 & 8.3 \\
\hline N 284 & 5.38 & No spectrum & 46.9 & 7.7 \\
\hline N 268 & 3.13 & Good spectrum no id & 47.7 & 8.6 \\
\hline N 509 & 1.50 & Weak spectrum no id & 23.9 & 7.9 \\
\hline N 207 & 0.38 & No spectrum & 57.4 & 8.8 \\
\hline N 212 & 0.33 & Weak spectrum no id & 57.0 & 8.5 \\
\hline N 403 & 0.31 & Weak spectrum no id & 31.8 & 8.5 \\
\hline N 1355 & 0.25 & Good spectrum no id & 44.1 & 8.0 \\
\hline N 68 & 0.12 & Weak spectrum no id & 89.1 & 6.4 \\
\hline I 8264 & 21.03 & Good spectrum no id & 13.7 & 6.6 \\
\hline I 683 & 3.36 & Weak spectrum no id & 72.9 & 6.3 \\
\hline I 961 & 2.58 & Good spectrum no id & 52.0 & 5.1 \\
\hline I 266 & 1.77 & No spectrum & 24.8 & 4.8 \\
\hline I 408 & 0.70 & Weak spectrum no id & 32.5 & 5.9 \\
\hline I 327 & 0.43 & Weak spectrum no id & 24.4 & 6.5 \\
\hline I 75 & 0.43 & No spectrum & 62.2 & 6.5 \\
\hline I 6585 & 0.42 & No spectrum & 30.2 & 6.0 \\
\hline I 8330 & 0.27 & No spectrum & 25.5 & 4.4 \\
\hline I 712 & 0.26 & No spectrum & 90.1 & 5.4 \\
\hline I 275 & 0.26 & No spectrum & 22.7 & 6.0 \\
\hline I 1196 & 0.22 & No spectrum & 24.4 & 6.1 \\
\hline I 270 & 0.22 & Good spectrum no id & 22.5 & 5.4 \\
\hline I 838 & 0.20 & No spectrum & 65.1 & 4.9 \\
\hline I 418 & 0.18 & No spectrum & 33.2 & 6.3 \\
\hline I 545 & 0.11 & No spectrum & 54.8 & 4.5 \\
\hline I 242 & 0.08 & Good spectrum no id & 20.6 & 5.0 \\
\hline I 8311 & 0.08 & Weak spectrum no id & 21.3 & 4.5 \\
\hline I 292 & 0.08 & Weak spectrum no id & 24.8 & 4.5 \\
\hline I 7495 & 0.04 & No spectrum & 30.2 & 5.6 \\
\hline
\end{tabular}

Unidentified protein spots with statistically significant changes in expression level expressed as \% IOD-ratio in neonatal BB-DP islets after IL- $1 \beta$ incubation in vitro compared to BB-DP islets without IL-1 $\beta$. The $\mathrm{M}_{\mathrm{r}}$ and $\mathrm{pI}$ obtained directly from the gels are given pre-pro forms of proteins since the theoretical values are based on the open reading fame only. For example calreticulin is present in two spots with a $\mathrm{M}_{\mathrm{r}}$ of respectively 39.9 and 120.7 whereas the theoretical value is 48 . Nevertheless for most proteins there are only minor differences between observed $\mathrm{M}_{\mathrm{r}}$ and $\mathrm{pI}$ values and theoretical values (Table 1).

In total, 45 different proteins and 12 modified forms of some of these proteins have been identified to change the expression after exposure to IL-1 $\beta$. Based on known or putative functions the 45 identified proteins (with modified forms 57) have been grouped as follows (in brackets, number of different proteins): proteins involved in (i) energy transduction and redox potentials $(n=8)$, (ii) glycolytic and Krebs cycle enzymes $(n=6)$, (iii) protein synthesis (including purin and pyrimidine synthesis, DNA and RNA synthesis, RNA processing and amino acid metabolism), chaperoning and protein folding $(n=14)$, (iv) signal transduction, regulation, differentiation and apoptosis $(n=6)$, (v) cellular defence $(n=2)$ and (vi) other functions $(n=9)$ (Table 1$)$.

\section{Discussion}

Proteome analysis comprising 2-DGE, mass spectrometry and bio-informatics offers the opportunity to identify different pathways involved in IL-1 $\beta$ induced beta-cell destruction. Mass spectrometry is at present the most powerful method for identifying proteins from 2-DG's [33].

For reasons outlined in the section "2-DGE and preparative gels", preparative gels from WF islets were used for mass spectrometry protein identification. This was mainly for financial reasons, but was feasible since all protein spots changing their expres- 
sion in IL- $1 \beta$ exposed BB-DP islets were also identifiable in the WF 2D-gels, and no protein spots were induced to expression de novo by IL- $1 \beta$ in the BB-DP islets. We have shown previously that RIN-cells express essentially all proteins found to change the expression in response to IL-1 $\beta$ in BB-DP rat islets [34].

Fewer protein spots changed expression upon IL-1 $\beta$ exposure in the BB-DP islets (82 spots) compared to WF islets (105 spots). A total of 32 proteins were "specific" for BB-DP islet responses to IL-1 $\beta$ in vitro and 44 proteins "specific" for WF rat islets, although several are from similar pathways and have similar functions in the two strains e.g. NADH dehydrogenase (BB-DP) and NADH-cytochrome B5 reductase (WF).

Several proteins were seen in more than one spot suggesting that these proteins undergo posttranslational modifications. Posttranslational modifications, e.g. phosphorylations, methylations or glycosylations are important for the function or activation of the protein [35].

The cytotoxic effect of cytokines on islets is inhibited by inhibitors of protein synthesis [36], suggesting that beta-cell destruction is an active intracellular process requiring synthesis of proteins. Several proteins have been reported to change expression after IL-1 $\beta$ exposure [37] e.g. iNOS, heat shock protein (HSP) 70, 90 and MnSOD representing a protective response $[38,39]$. On this basis we hypothesized that cytokines induce a race between protective and deleterious events, and that in beta cells the deleterious events prevail.

We have shown previously that IL- $1 \beta$ induces PIPP in islets $[8,9,10]$. PIPPs comprises up-regulation and down-regulation of protein expression and/or gelposition-shifts resulting from post-translatory modifications. Consequently, when we describe the expression of a protein as up-regulated or down-regulated, this can reflect a change of expression in the protein itself or a modified form of that protein.

The findings should be interpreted with some caution because they reflect the specific experimental conditions e.g. concentration of IL-1 $\beta$, exposure time, labelling interval, and the general culture conditions. The study does not distinguish primary and secondary changes in time or in importance. To evaluate the effects of each of these factors a large series of experiments would be necessary.

Not surprisingly, results from a proteome study differ to a large extent from the findings of mRNA expression profile changes in comparable experiments $[40,41]$. Generally, correlations between protein and the corresponding mRNA expression are poor [42]. The possibility to characterize the protein expression profile in a cell or tissue under specific conditions and at a given time point, reflecting the metabolic and functional status of these specific conditions and the exact time point, is the hallmark of proteome analysis [43].

Energy transduction, redox potentials, glycolytic and Krebs cycle enzymes (fourteen different proteins). IL-1 $\beta$ induces nitric oxide production in the beta cells which in turn nitrosylates the Fe-S complex in certain enzymes [44]. This reduces the activity of e.g. mitochondrial aconitase [45] and leads to the inhibition of the oxidation of glucose in the Krebs cycle. This is in agreement with the finding that glyceralaldehyde3-phosphate dehydrogenase, pyruvate kinase M2 isozyme, aconitate hydratase, isocitrate dehydrogenase and malate dehydrogenase precursor (three spots) are all involved in glycolysis or Krebs cycle and are down-regulated.

Seven proteins involved in energy transduction and redox potentials are down-regulated in response to IL$1 \beta$ exposure. Taken together this suggest that energy production is reduced by IL-1 $\beta$ in BB-DP rat islets, as was the case in WF islets [10].

Protein synthesis (including purin and pyrimidine synthesis, DNA and RNA synthesis, RNA processing, amino acid metabolism), chaperones and protein folding (fourteen proteins). Three identified proteins, 5-aminoimidazole-4-carboxamide ribonucleotide formyltranferase, UMP-CMP kinase and adenine phosphoribosyltransferase, are involved in the synthesis of purine, pyrimidine, nucleosides and nucleotides and important for RNA and DNA synthesis [46, 47] and two proteins, heterogeneous nuclear ribonucleoprotein A2/B1 and heterogeneous nuclear ribonucleoprotein $M$ (M4 protein deletion mutant), in processing of pre-mRNA [48, 49] were all down-regulated. Downregulation of gene transcription and protein synthesis by IL- $1 \beta$ has been shown in several studies $[8,38,50$, $51,52]$.

Endoplasmin precursor, found with a $78 \mathrm{kDa}$ glucose regulated protein (GRP78) in a down-regulated spot, belongs to the HSP 90 family [53] and has serine kinase activity that is enhanced by association with GRP78 [54]. GRP78, a member of the HSP 70 family (three spots; one up-regulated, one down-regulated and one together with endoplasmin in a downregulated spot) is involved in the folding and assembly of proteins in the endoplasmatic reticulum [55]. Endoplasmic reticulum protein ERP 29 is involved in protein secretory events. IL- $1 \beta$ exposure down-regulated this protein. Protein disulfide isomerase, which is necessary for molecular chaperoning of glycoprotein biosynthesis [56] and probable disulfide isomerase P5 catalysing formation and re-arrangement of disulfidebonds in proteins, were both down-regulated. All of these proteins are able to bind the important cellular second messenger and regulator, calcium, like calreticulin, found in two up-regulated spots [57, $58,59]$. 
Increased HSP70 expression has been shown to diminish the inhibitory effect of IL-1 $\beta$ on islet insulin secretion and nitric oxide-induced mitochondrial impairment $[16,60,61]$.

Signal transduction, regulation, differentiation and apoptosis (six proteins). IL-1 $\beta$ induces cell death through different pathways, e.g. apoptosis $[62,63$, 64]. Galectin-3, which inhibits apoptosis $[65,66,67]$, was up-regulated in three spots. Expression of eukaryotic initiation factor 4A-like NUK-34, involved in transcriptional and translational regulation [68], was increased suggesting activation of protein synthesis. Toad 64, present during neurogenesis and important for axon growing [69], was up-regulated after IL-1 $\beta$ exposure. The calcium binding protein secretagogin, specific for neuroendocrine cells that has extensive homology to the anti-apoptotic calbindin D-28 k [70] involved in cell growth and maturation [71], was down-regulated. Calreticulin, another calcium binding protein, found to be up-regulated in two spots, functions as a modulator of gene transcription via nuclear hormone receptors (glucocorticoid and androgen receptors) $[72,73]$.

Craniofacial development protein 1, not previously described in islets of Langerhans, could have multiple functions during embryonic development, e.g. in the developing neuroepithelium [74]. Expression of craniofacial development protein 1 was increased, suggesting a function of this protein in the plethora of proteins induced in islets by IL- $1 \beta$.

Voltage-dependent anion channel protein was identified in a down-regulated spot together with L-3-hydroxyacyl-CoA dehydrogenase precursor. The voltage dependent anion channel protein forms pores in the outer mitochondrial membrane serving as the permeability pathway for metabolite flux between the cytoplasm and mitochondria [75]. Bcl2 proteins bind to the channel and regulates mitochondrial membrane potential, permeability and release of cytochrome $\mathrm{c}$ during apoptosis $[76,77]$.

Cellular defence (two proteins). Free radicals (e.g. nitric oxide and oxygen-derived radicals) possibly play a role in the destruction of beta cells [3]. Catalase, which protects cells from the toxic effects by hydrolysing hydrogen peroxide, was up-regulated in response to IL- $1 \beta$ exposure, suggesting the presence of hydrogen peroxide in BB-DP rat islets. The presence of the toxic peroxynitrite is a signal to higher production of catalase and glutathione peroxidase to convert peroxinitrite to oxygen and water. Overexpression of catalase, superoxide dismutase and glutathione peroxidase in rat insulinoma (RIN) cells protects against the toxicity of nitric oxide [78] as well as against cytokines [11]. The observed increased expression of catalase (threefold) in the BB-DP islets is apparently insufficient to protect against the IL-1 $\beta$ in- duced free radicals. Described strain differences in rat islet sensitivity to IL-1 $\beta$ and nitric oxide might be due to different capacities to mount a free radical defence [14]. Hereditary catalase deficiencies and polymorphisms in the MnSOD gene are reported to increase the risk for Type I diabetes [79, 80, 81].

Expression of glutathione synthetase, important for protecting cells from oxidative damage [78, 82, 83], was reduced eightfold, further suggesting that IL-1 $\beta$ reduces cellular defence against oxygen-derived free radicals in BB-DP rat islets.

These two defence proteins, catalase and glutathione synthetase, changed expression due to IL-1 $\beta$ exposure in BB-DP rats but not in WF rat islets. This indicates that the two strains respond differently in either production of free radicals or in the defence from free radicals induced by IL- $1 \beta$ exposure.

Other functions: hormone and neurotransmitter metabolism (five proteins). Insulin and other hormones are formed through a series of precursors that are processed by different enzymes before they become biologically active. Proinsulin is processed by the calcium dependent serine proteases neuroendocrine convertase 1 and 2 . Inherited defects in prohormone processing enzymes have been found associated with metabolic syndromes and disorders $[84,85]$. In IL-1 $\beta$ exposed islets both neuroendocrine convertase 1 and 2 are down-regulated more than fivefold explaining decreased insulin release after IL- $1 \beta$ exposure of islets in vitro [86]. In human islets exposed to cytokines expression of neuroendocrine convertase 1 and 2 is reduced [87].

The 25-Dx, a receptor for progesterone, was downregulated after IL-1 $\beta$ exposure. 25-Dx has $71 \%$ homology with the transmembrane domain of the precursor for the IL-6 receptor [88]. Amyloid betapeptide binding protein, involved in androgen metabolism and suggested to be involved in apoptosis and amyloid toxicity [89], was down-regulated by IL-1 $\beta$.

Beta-alanine oxoglutarate aminotransferase (GABAtransaminase), responsible for the catabolism of the major inhibitory neurotransmitter gamma-aminobutyric acid (GABA), was down-regulated in IL-1 $\beta$ exposed BB-DP islets. GABA is synthesized by glutamic acid decarboxylase (GAD) and could be involved in islet-cell development. GAD has been associated with Type I diabetes in humans $[90,91]$ and in non-obese diabetic (NOD) mice $[92,93,94]$. GAD expression in islets is inhibited by IL-1 $\beta$ exposure [95].

Miscellaneous functions (two proteins). The 5-aminolevulinate synthase precusor is a nuclear-encoded mitochondrial enzyme in the haem biosynthetic pathway. IL-1 $\beta$ down-regulated its expression and might thereby increase the beta-cell susceptibility to IL-1 $\beta$ due to lower substrates for catalase production, since catalase is a haem containing protein. 
Cytomegalovirus protein immediate-early protein 1 , able to transactivate heterologous promoters [96] in rat cytomegalovirus, was down-regulated in the BB-DP islets.

The complexity of the effects of IL-1 $\beta$ on islets, described here by PIPP, substantiates the hypothesis, that development of Type I diabetes is the result of a collective, dynamic instability, rather than the result of a single factor [97].

Taken together, proteome analysis of IL- $1 \beta$ exposed neonatal BB-DP islets showed that IL-1 $\beta$ induced statistically significant changes in the expression of many proteins. Several proteins were identical and others were from similar pathways in both strains, suggesting that several but similar routes can lead to impaired beta-cell function and destruction in BB-DP and WF rats. Several proteins, previously not described in islets of Langerhans, were identified (Table 1 ).

In conclusion, we have shown that the combination of 2-DGE and mass spectrometry is a powerful method for identifying proteins involved in the cytotoxic effects after IL-1 $\beta$ exposure in rat islets. Whether similar changes in protein expression are seen in vivo in prediabetic BB-DP rats is currently under investigation.

Acknowledgements. The skilful, technical assistance of E. Schjerning, B. Born, L. Christensen, A. Lorentzen, and V. Mose Larsen is highly appreciated as is the secretarial assistance of N. Meier. The study was in part supported by the Danish Diabetes Association, University of Copenhagen, King Christian X's Foundation, the Højmosegård Foundation, Juvenile Diabetes Foundation International (Grant no. DK-96-012 and RFA, grant no. 998005), Novo Nordisk A/S, Biotech grant from Danish Medical Research Council (grant no. 9502027) and The Sehested Hansen Foundation.

\section{References}

1. Gepts W (1965) Pathologic anatomy of the pancreas in juvenile diabetes mellitus. Diabetes 14:619-633

2. Junker K, Egeberg J, Kromann H, Nerup J (1977) An autopsy study of the islets of Langerhans in acute onset juvenile diabetes mellitus. Acta Pathol Microbiol Scand [A] 85:699-706

3. Nerup J, Mandrup-Poulsen T, Helqvist S et al. (1994) On the pathogenesis of IDDM. Diabetologia 37 [Suppl 2]: S82-S89

4. Corbett JA, McDaniel ML (1995) Intraislet release of interleukin 1 inhibits b cell expression of inducible nitric oxide synthase. J Exp Med 181:559-568

5. Asayama K, Kooy NW, Burr IM (1986) Effect of vitamin E deficiency and selenium deficiency on insulin secretory reserve and free radical scavenging systems in islets: decrease of islet manganosuperoxide dismutase. J Lab Clin Med 107:459-464

6. Sumoski W, Baquerizo H, Rabinovitch A (1989) Oxygen free radical scavengers protect rat islet cells from damage by cytokines. Diabetologia 32:792-796
7. Mandrup-Poulsen T (1996) The role of interleukin-1 in the pathogenesis of insulin-dependent diabetes mellitus. Diabetologia 39:1005-1029

8. Andersen HU, Fey SJ, Mose Larsen P et al. (1997) Interleukin-1beta induced changes in the protein expression of rat islets. Electrophoresis 18:2091-2103

9. John N, Andersen H, Fey S et al. (2000) Cytokine or chemically-derived nitric oxide alters the expression of proteins detected by two-dimensional gel electrophoresis in neonatal rat islets of Langerhans. Diabetes 49:1819-1829

10. Mose Larsen P, Fey SJ, Larsen MR et al. (2001) Proteome analysis of IL-1 $\beta$ induced changes in protein expression in rat islets of Langerhans. Diabetes 50:1056-1063

11. Lortz S, Tiedge M, Nachtwey T, Karlsen AE, Nerup J, Lenzen S (2000) Protection of insulin-producing RINm5F cells against cytokine-mediated toxicity through overexpression of antioxidant enzymes. Diabetes 49:1123-1130

12. Bone AJ (2000) Animal models of type I diabetes. Current Opin Oncol Endocr Metab Invest Drugs 2:192-200

13. Nakhooda AF, Like AA, Chappel CI, Murray FT, Marliss EB (1977) The spontaneously diabetic Wistar rat. Metabolic and morphologic studies. Diabetes 26:100-112

14. Andersen HU, Mandrup-Poulsen T, Egeberg J, Helqvist S, Nerup J (1989) Genetically determined differences in newborn rat islet sensitivity to interleukin-1 in vitro: no association with the diabetes prone phenotype in the BB-rat. Acta Endocrinol 120:92-98

15. Reimers JI, Andersen HU, Mauricio D et al. (1996) Strain dependent differences in sensitivity of rat beta-cells to IL-1beta in vitro and in vivo: association with islet nitric oxide synthesis. Diabetes 45:771-778

16. Bellmann K, Hui L, Radons J, Burkart V, Kolb H (1997) Low stress response enhances vulnerability of islet cells in diabetes-prone BB rats. Diabetes 46:232-236

17. Christensen UB, Larsen PM, Fey SJ et al. (2000) Islet protein expression changes during diabetes development in islet syngrafts in BB-DP rats and during rejection of BB-DP islet allografts. Autoimmunity 32:1-15

18. Brunstedt J, Nielsen JH, Lernmark $\AA$, and The Hagedorn Study Group (1984) Isolation of islets from mice and rats. In: Larner J, Pohl SL (eds) Methods in diabetes research (Laboratory methods, part C), vol 1. Wiley \& Sons, New York, pp 254-288

19. O'Farrell PZ, Goodman HM, O'Farrell PH (1977) High resolution two dimentional electrophoresis of basic as well as acidic proteins. Cell 12:1133-1142

20. Fey SJ, Mose Larsen P, Biskjær N (1984) The protein variation in basal cells and certain basal cell related benign and malignant diseases. Faculty of Natural Science, University of Århus, Denmark

21. Fey SJ, Nawrocki A, Larsen MR et al. (1997) Proteome analysis of Saccharomyces cerevisiae: a methodological outline. Electrophoresis 18:1361-1372

22. Compute $\mathrm{pl} / \mathrm{Mw}$ tool at the ExPASy Molecular Biology Server, http://www.expasy.ch/tools/pi_tool.html, access date 26-06-2001, last update date 19-03-2002

23. Rosenfeld J, Capdevielle J, Guillemot JC, Ferrara P (1992) In-gel digestion of proteins for internal sequence analysis after one- or two-dimensional gel electrophoresis. Anal Biochem 203:173-179

24. Shevchenko A, Wilm M, Vorm O, Mann M (1996) Mass spectrometric sequencing of proteins from silver stained polyacrylamide gels. Anal Chem 68:850-858

25. Nawrocki A, Larsen MR, Podtelejnikov AV et al. (1998) Correlation of acidic and basic, ampholyte and immobilised $\mathrm{pH}$ gradient 2D gel patterns based on mass spectrometric identification. Electrophoresis 19:1024-1035 
26. Kussmann M, Nordhoff E, Nielsen HR et al. (1997) MALDI-mass spectrometry sample preparation techniques designed for various peptide and protein analytes. J Mass Spectrom 32:593-601

27. European Bioinformatics Institute, http://www.ebi.ac.uk, access date 05-15-2000, last update date 20-08-2002

28. Mann M, Højrup P, Roepstorff P (1993) Use of mass spectrometric molecular weight information to identify proteins in sequence databases. Biol Mass Spectrom 22:338345

29. SWISS-PROT, http://www.expasy.ch, access date 19-03-2001, last update year 29-05-2002

30. PIR, http://www.sanger.ac.uk/DataSearch, access date 15-05-2000, last update date 15-08-2002

31. The National Centre for Biotechnology Information (NCBI), http://www.ncbi.nlm.nih.gov, access date 26-06-2001, last update date 17-08-2002

32. Jensen ON, Larsen MR, Roepstorff P (1998) Mass spectrometric identification and microcharacterization of proteins from electrophoretic gels: Strategies and applications. Proteins 33:74-89

33. Lahm HW, Langen H (2000) Mass spectrometry: a tool for the identification of proteins separated by gels. Electrophoresis 21:2105-2114

34. Karlsen AE (2001) Personal communication, Copenhagen

35. Miklos GLG, Maleszka R (2001) Protein functions and biological contexts. Proteomics 1:169-178

36. Welsh N, Bendtzen K, Sandler S (1991) Influence of protease on inhibitory and stimulatory effects of interleukin 1 beta on beta-cell function. Diabetes 40:290-294

37. Andersen HU, Larsen PM, Fey SJ, Karlsen AE, MandrupPoulsen T, Nerup J (1995) Two-dimensional gel electrophoresis of rat islet proteins. Interleukin 1 beta-induced changes in protein expression are reduced by L-arginine depletion and nicotinamide. Diabetes 44:400-407

38. Helqvist S, Polla BS, Johannesen J, Nerup J (1991) Heat shock protein induction in rat pancreatic islets by recombinant human interleukin 1 beta. Diabetologia 34:150 156

39. Borg LAH, Cagliero E, Sandler S, Welsh N, Eizirik DL (1992) Interleukin-1 $\beta$ increases the activity of superoxide dismutase in rat pancreatic islets. Endocrinology 130:28512857

40. Rieneck K, Bovin LF, Josefsen K, Buschard K, Svenson M, Bendtzen K (2000) Massive parallel gene expression profiling of RINm5F pancreatic islet b-cells stimulated with interleukin-1b. APMIS 108:855-872

41. Cardozo AK, Kruhøffer M, Leeman R, Ørntoft T, Eizirik DL (2001) Identification of novel cytokine induced genes in pancreatic b-cells by high density oligonucleotide arrays. Diabetes 50:909-920

42. Gygi SP, Rochon Y, Franza BR, Aebersold R (1999) Correlation between protein and mRNA abundance in yeast. Mol Cell Biol 19:1720-1730

43. Pociot F, Karlsen AE (2002) Combined genome and proteome approach to identify new susceptibility genes. Am J Med Genet 115:55-60

44. Corbett JA, Lancaster JR, Sweetland MA, McDaniel ML (1991) Interleukin-1 beta-induced formation of EPRdetectable iron-nitrosyl complexes in islets of Langerhans. Role of nitric oxide in interleukin-1 beta-induced inhibition of insulin secretion. J Biol Chem 266:21351-21354

45. Welsh N, Eizirik DL, Bendtzen K, Sandler S (1991) Interleukin-1 beta-induced nitric oxide production in isolated rat pancreatic islets requires gene transcription and may lead to inhibition of the Krebs cycle enzyme aconitase. Endocrinology 129:3167-3173
46. Ni L, Guan K, Zalkin H, Dixon JE (1991) De novo purine nucleotide biosynthesis: cloning, sequencing and expression of a chicken PurH cDNA encoding 5-aminoimidazole4-carboxamide-ribonucleotide transformylase-IMP cyclohydrolase. Gene 106:197-205

47. Moriwaki Y, Yamamoto T, Higashino K (1999) Enzymes involved in purine metabolism-a review of histochemical localization and functional implications. Histol Histopathol $14: 1321-1340$

48. Biamonti G, Ruggiu M, Saccone S, Dellavalle G, Riva S (1994) 2 homologous genes, originated by duplication, encode the human hnrnp protein-a2 and protein-a1. Nucleic Acids Res 22:1996-2002

49. Datar KV, Dreyfuss G, Swanson mass spectrometry (1993) The human hnRNP M proteins: identification of a methionine/arginine-rich repeat motif in ribonucleoproteins. Nucleic Acids Res 21:439-446

50. Eizirik DL, Bjorklund A, Welsh N (1993) Interleukin-1induced expression of nitric oxide synthase in insulinproducing cells is preceded by c-fos induction and depends on gene transcription and protein synthesis. FEBS Lett 317:62-66

51. Chen MC, Schuit F, Pipeleers DG, Eizirik DL (1999) IL-1beta induces serine protease inhibitor 3 (SPI-3) gene expression in rat pancreatic beta-cells. Detection by differential display of messenger RNA. Cytokine 11:856-862

52. Spinas GA, Hansen BS, Linde S et al. (1987) Interleukin 1 dose-dependently affects the biosynthesis of (pro)insulin in isolated rat islets of Langerhans. Diabetologia 30:474-480

53. Riera M, Roher N, Miro F et al. (1999) Association of protein kinase CK2 with eukaryotic translation initiation factor eIF-2 and with grp94/endoplasmin. Mol Cell Biochem 191:97-104

54. Ramakrishnan M, Schonthal AH, Lee AS (1997) Endoplasmic reticulum stress-inducible protein GRP94 is associated with an $\mathrm{Mg} 2+-$ dependent serine kinase activity modulated by Ca2+ and GRP78/BiP. J Cell Physiol 170:115-129

55. Hendershot LM, Valentine VA, Lee AS, Morris SW, Shapiro DN (1994) Localization of the gene encoding human BiP/GRP78, the endoplasmic reticulum cognate of the HSP70 family, to chromosome 9q34. Genomics 20:281284

56. Oliver JD, Wal FJ van der, Bulleid NJ, High S (1997) Interaction of the thiol-dependent reductase ERp57 with nascent glycoproteins. Science 275:86-88

57. Nakamura M, Yamanobe T, Suyemitsu T et al. (1991) A new membrane-associated $\mathrm{Ca}(2+)$-binding protein of rat spermatogenic cells: its purification and characterization. Biochem Biophys Res Commun 176:1358-1364

58. Ashby MC, Tepikin AV (2001) ER calcium and the functions of intracellular organelles. Semin Cell Dev Biol 12:11-17

59. Bootman MD, Collins TJ, Peppiatt CM et al. (2001) Calcium signalling - an overview. Semin Cell Dev Biol 12:3-10

60. Bellmann K, Jaattela M, Wissing D, Burkart V, Kolb H (1996) Heat shock protein hsp70 overexpression confers resistance against nitric oxide. FEBS Lett 391:185-188

61. Scarim AL, Heitmeier MR, Corbett JA (1998) Heat shock inhibits cytokine-induced nitric oxide synthase expression by rat and human islets. Endocrinology 139:5050-5057

62. Ankarcrona M, Dypbukt JM, Brune B, Nicotera P (1994) Interleukin-1 beta-induced nitric oxide production activates apoptosis in pancreatic RINm5F cells. Exp Cell Res 213:172-177

63. Kaneto H, Fujii J, Seo HG et al. (1995) Apoptotic celldeath triggered by nitric-oxide in pancreatic beta-cells. Diabetes 44:733-738 
64. Vassiliadis S, Dragiotis V, Protopapadakis E et al. (1999) The destructive action of IL-1alpha and IL-1beta in IDDM is a multistage process: evidence and confirmation by apoptotic studies, induction of intermediates and electron microscopy. Med Inf (Lond) 8:85-91

65. Lotz MM, Andrews CW, Korzelius CA et al. (1993) Decreased expression of Mac-2 (carbohydrate binding protein 35) and loss of its nuclear localization are associated with the neoplastic progression of colon carcinoma. Proc Natl Acad Sci USA 90:3466-3470

66. Hsu DK, Dowling CA, Jeng KCG, Chen JT, Yang RY, Liu FT (1999) Galectin-3 expression is induced in cirrhotic liver and hepatocellular carcinoma. Int J Cancer 81:519526

67. Sparre T, Nielsen K, Mose Larsen P et al. (2001) Proteome analysis used in the discovery of molecular mechanisms involved in the pathogenesis of type 1 diabetes mellitus. In: 2001 Congress, Functional Proteomics, Lausanne. FontisMedia SA, pp 47-52

68. Sudo K, Takahashi E, Nakamura Y (1995) Isolation and mapping of the human EIF4A2 gene homologous to the murine protein synthesis initiation factor 4A-II gene Eif4a2. Cytogenet Cell Genet 71:385-388

69. Minturn JE, Fryer HJ, Geschwind DH, Hockfield S (1995) TOAD-64, a gene expressed early in neuronal differentiation in the rat, is related to unc-33, a C. elegans gene involved in axon outgrowth. J Neurosci 15:6757-6766

70. Rabinovitch A, Suarez-Pinzon W, Strynadka K, Sooy K, Christakos S (1999) Calbindin-D28k overexpression prevents cytokine-induced apoptosis in pancreatic islet betacells. Diabetes 48:A427-A428

71. Wagner L, Oliyarnyk O, Gartner W, Nowotny P, Groeger M, Kaserer K, Waldhausl W, Pasternack MS (2000) Cloning and expression of secretagogin, a novel neuroendocrine- and pancreatic islet of Langerhansspecific Ca2+-binding protein. J Biol Chem 275:247404751

72. Burns K, Duggan B, Atkinson EA et al. (1994) Modulation of gene expression by calreticulin binding to the glucocorticoid receptor. Nature 367:476-480

73. Dedhar S, Rennie PS, Shago M et al. (1994) Inhibition of nuclear hormone receptor activity by calreticulin. Nature 367:480-483

74. Diekwisch TG, Marches F, Williams A, Luan X (1999) Cloning, gene expression, and characterization of CP27, a novel gene in mouse embryogenesis. Gene 235:19-30

75. Hodge T, Colombini M (1997) Regulation of metabolite flux through voltage-gating of vdac channels. J Memb Biol 157:271-279

76. Shimizu S, Narita M, Tsujimoto Y (1999) Bcl-2 family proteins regulate the release of apoptogenic cytochrome $\mathrm{c}$ by the mitochondrial channel VDAC. Nature 399:483-487

77. Tsujimoto Y, Shimizu S (2000) VDAC regulation by the Bcl-2 family of proteins. Cell Death Differentiation 7:1174-1181

78. Tiedge M, Lortz S, Munday R, Lenzen S (1999) Protection against the co-operative toxicity of nitric oxide and oxygen free radicals by overexpression of antioxidant enzymes in bioengineered insulin-producing RINm5F cells. Diabetologia 42:849-855

79. Pociot F, Lorenzen T, Nerup J (1993) A manganese superoxide dismutase (SOD2) gene polymorphism in insulindependent diabetes mellitus. Dis Markers 11:267-274
80. Pociot F, Ronningen KS, Bergholdt R et al. (1994) Genetic susceptibility markers in Danish patients with type 1 (insulin-dependent) diabetes - evidence for polygenicity in man. Danish Study Group of Diabetes in Childhood. Autoimmunity 19:169-178

81. Goth L, Eaton JW (2000) Hereditary catalase deficiencies and increased risk of diabetes. Lancet 356:1820-1821

82. Meister A, Anderson ME (1983) Glutathione. Annu Rev Biochem 52:711-760

83. Uhlig S, Wendel A (1992) The physiological consequences of glutathione variations. Life Sci 51:1083-1094

84. Steiner DF, Rouille Y, Gong Q, Martin S, Carroll R, Chan SJ (1996) The role of prohormone convertases in insulin biosynthesis: evidence for inherited defects in their action in man and experimental animals. Diabetes Metab 22:94-104

85. Canaff L, Bennett HP, Hendy GN (1999) Peptide hormone precursor processing: getting sorted? Mol Cell Endocrinol 156:1-6

86. Mandrup-Poulsen T, Bendtzen K, Nerup J, Dinarello CA, Svenson M, Nielsen JH (1986) Affinity-purified human interleukin I is cytotoxic to isolated islets of Langerhans. Diabetologia 29:63-67

87. Hostens K, Pavlovic D, Zambre Y et al. (1999) Exposure of human islets to cytokines can result in disproportionately elevated proinsulin release. J Clin Invest 104:67-72

88. Selmin O, Lucier GW, Clark GC et al. (1996) Isolation and characterization of a novel gene induced by 2,3,7,8-tetrachlorodibenzo-p-dioxin in rat liver. Carcinogenesis 17:2609-2615

89. Oppermann UC, Salim S, Tjernberg LO, Terenius L, Jornvall H (1999) Binding of amyloid beta-peptide to mitochondrial hydroxyacyl-CoA dehydrogenase (ERAB): regulation of an SDR enzyme activity with implications for apoptosis in Alzheimer's disease. FEBS Lett 451:238-242

90. Baekkeskov S, Aanstoot HJ, Christgau S et al. (1990) Identification of the $64 \mathrm{~K}$ autoantigen in insulin-dependent diabetes as the GABA-synthesizing enzyme glutamic acid decarboxylase. Nature 347:151-156

91. Karlsen AE, Hagopian WA, Grubin CE et al.(1991) Cloning and primary structure of a human islet isoform of glutamic acid decarboxylase from chromosome 10. Proc Natl Acad Sci USA 88:8337-8341

92. Kash SF, Condie BG, Baekkeskov S (1999) Glutamate decarboxylase and GABA in pancreatic islets: lessons from knock-out mice. Horm Metab Res 31:340-344

93. Chessler SD, Lernmark A (2000) The role of glutamic acid decarboxylase and GABA in the pancreas and diabetes. In: Martin DL, Olsen RW (eds) GABA in the nervous sytem: the view at fifty years. Book News, Portland, pp 471484

94. Baekkeskov S, Kanaani J, Jaume JC, Kash S (2000) Does GAD have a unique role in triggering IDDM? J Autoimmun 15:279-286

95. Hao W, Palmer JP (1995) The effect of cytokines on expression of glutamic-acid decarboxylase- 65 in cultured islets. Autoimmunity 22:209-218

96. Sandford GR, Ho K, Burns WH (1993) Characterization of the major locus of immediate-early genes of rat cytomegalovirus. J Virol 67:4093-4103

97. Freiesleben-De B, Bak P, Pociot F, Karlsen AE, Nerup J (1999) Onset of type 1 diabetes: a dynamical instability. Diabetes 48:1677-1685 